\title{
Erratum to: Diagnostics to Look beyond the Normal Appearing Brain Tissue (NABT)? A Neuroimaging Study of Patients with Primary Headache and NABT Using Magnetization Transfer Imaging and Diffusion Magnetic Resonance
}

\author{
Y. Y. Beckmann · Ş. Eren · F. Gelal · O. Cancuri $\cdot$ V. Özdemir
}

Received: 8 June 2015 / Accepted: 8 June 2015 / Published online: 3 July 2015

(C) Springer-Verlag Berlin Heidelberg 2015

Erratum to:

Clin Neuroradiol

DOI 10.1007/s00062-013-0203-4

There was an error in the authors name of the article

The correct name is:

O. Cancuri

The online version of the original article can be found under doi:10.1007/s00062-013-0203-4

Y. Y. Beckmann, MD $(\bowtie) \cdot$ Ş. Eren, MD

Department of Neurology, Atatürk Training and Research,

Hospital, Faculty of Medicine, Izmir Katip Celebi University,

Atatürk Eğitim ve Araştırma Hastanesi, Nöroloji Kliniği, Basın

Sitesi,

İzmir, Turkey

e-mail: ybeckmann@gmail.com

F. Gelal, MD · O. Cancuri, MD

Department of Radiology, Atatürk Training and Research

Hospital, Faculty of Medicine, Izmir Katip Celebi University,

İzmir, Turkey

V. Özdemir, MD, PhD

Centre of Genomics and Policy, Department of Human Genetics,

Faculty of Medicine, McGill University,

Montreal, QC, Canada 